\title{
СТРУКТУРА ВИЩОГО УПРАВЛІННЯ ВІЙСЬК УКРАЇНСЬКОЇ НАРОДНОЇ РЕСПУБЛІКИ ЗА ЧАСІВ ЦЕНТРАЛЬНОЇ РАДИ (квітень 1918 р.) I ДИРЕКТОРІЇ (лютий 1919 р.): СПІЛЬНЕ І ВІДМІННЕ
}

Структура вищого управління військ УНР за часів Центральної Ради (в квітні 1918 р.) і Директорії (в лютому 1919 р.) була досить функціональною. Система 1919 р. була більш вдалою - виправлено попередні помилки (створено Головне управління Генерального штабу; Генеральний штаб контролював Головний штаб та Головну шкільну і Головну геодезичну управи). Структура вищого військового управління відповідала вимогам військово-політичної ситуащії. В квітні 1918 р. УНР перебувала під захистом військ Німеччини та Австро-Угорщини. В УНР діяла парламентська модель - домінувала ЦР (на чолі Збройних Сил стояв Військовий міністр). В лютому 1919 р. УНР не мала міжнародної підтримки і втратила більшість територї (Червона Армія і Військо Польське розгромили українські війська). На чолі УНР стояла Директорія, в якій домінував Головний Отаман С. Петлюра (він очолив Збройні Сили).

Ключові слова: Вище військове управління, Українська Народна Республіка, Центральна Рада, Директорія, Збройні Сили, Військовий міністр, Генеральний штаб, Головний штаб.

Під час революційних зрушень 1917-1921 рр. на території України постійно точилися як дрібні збройні сутички, так і крупні бойові операції за участю цілих армій. За таких обставин для новостворених державних організмів визначальну роль відігравала здатність боронитися як від зовнішніх, так і внутрішніх ворогів. 3 цією метою створювалися відповідні збройні формування, які поступово набували ознак повноцінних Збройних Сил 3 усіма необхідними атрибутами. Зрозуміло, що керівництво цими формуваннями здійснювали структури вищого військового управління.

Задунайський Вадим Васильович, доктор історичних наук, професор, професор кафедри світової історії нового і новітнього часу, Український католицький університет, м. Львів.

(C) Задунайський В.В., 2017 
Треба підкреслити, що впродовж револющійної доби мали місце різні підходи щодо пріоритетів і напрямів державного будівництва, які суттево позначилися на тенденціях становлення й розвитку Збройних Сил. Якщо йдеться про Українську Народну Республіку (УНР), то вже за часів Центральної Ради (ЦР) існували відмінні концепції розвитку держави й військової системи. Ще більш помітними такі відмінності стали за часів відновлення УНР під проводом Директорії. Все це обумовило не лише складність та уривчастість українського військового будівництва впродовж 1917-1921 рр., але i його пряму залежність як від зовнішньополітичної ситуації, так і від військово-політичного й соціальноекономічного становища в самій Україні. Вагоме значення мав i попередній військово-організаційний досвід українських військових діячів, здебільшого пов’язаний з армією Російської імперії.

3 огляду на зазначене видається цілком слушним виявити й порівняти основні структури вищого військового управління УНР за часів як ЦР, так i Директорії, не забуваючи й про дореволюційний досвід. У першому випадку варто проаналізувати досить змістовну структуру, запровадження якої розпочалося у квітні 1918 р., а у другому - в лютому 1919 р. Саме у зазначений час в обох державних утвореннях здійснювались спроби утворення повноцінної системи Збройних Сил (у тому числі й структури вищого військового управління). Завдяки цьому з'явиться можливість порівняти пріоритети відповідного аспекту українського військового будівництва під час зазначених періодів революційної доби.

Отже, огляд та порівняння структур вищого військового управління УНР, оголошених у квітні 1918 р. і лютому 1919 р., сприятиме комплексному розумінню особливостей тогочасних революційних зрушень на території України. За таких обставин дослідження зазначеної проблематики $є$ цілком актуальним заслуговує уваги науковців.

Слід наголосити, що різноманітні аспекти історії Українського Війська революційної доби почали 
розробляти ще безпосередні учасники тих подій, які опинилися в еміграції [1; 2; 3; 4]. Згодом з'явилась узагальнююча праця «Історія Українського Війська», в якій міститься й коротка інформація про структуру військового управління за часів ЦР [5]. За радянських часів відповідна тематика не досліджувалась, а революційні події в Україні подавались упереджено [6; 7; 8]. В сучасній українській історіографії дедалі активніше розробляеться історія Українського Війська, у тому числі й робляться спроби подати узагальнений огляд військового будівництва [9; 10]. Має місце й успішне дослідження історії українських військових фрормувань в окремих регіонах та окремих родів військ $[11 ; 12 ; 13]$. Останнім часом набуло поширення й дослідження персоналій українського генералітету революційної доби $[14 ; 15 ; 16]$. Попри зазначене, все ще не відбулось комплексне порівняння розвитку структур вищого військового управління УНР впродовж відповідного періоду.

Автор статті періодично звертав увагу на різноманітні аспекти військового будівництва в УНР, але теж досі не здійснив комплексного порівняння структур вищого військового управління 3 урахуванням досвіду дореволюційної російської армії [17; 18; 19; 20; 21; 22].

Треба наголосити, що й зарубіжні науковці, зокрема польські, теж не провели порівняння структур вищого військового управління Українського Війська за часів УНР. При цьому має місце як публікація комплексних оглядів історії українських військових формувань, так і дослідження військової співпраці польських і українських збройних утворень [23; 24].

Отже, в історіографрії все ще відсутній комплексний огляд-порівняння структур вищого військового управління Збройних Сил УНР за часів ЦР та Директорії. Все це обумовлює актуальність звернення до цієї проблематики у пропонованій статті. Ї̈ метою й буде вияв структур вищого військового управління Збройних Сил УНР у квітні 1918 р. (за часів ЦР) та лютому 1919 р. (за Директорії, але без огляду структур Галицької Армії), та здійснення їх порівняння у відповідному військово-політичному 
контексті тих часів та з урахуванням досвіду дореволюційної армії Російської імперії. Для досягнення цього передбачається виконання певних завдань: оглянути вищі командні структури армї; проаналізувати їх повноваження; виявити пріоритетні посади і структури; наголосити на впливах тогочасних військово-політичних реалій та попереднього військового досвіду.

Джерельною базою представленого дослідження стали здебільшого матеріали, почерпнуті в Центральному державному архіві вищих органів влади та управління України (далі ЦДАВО).

Використані джерела, науково-дослідницькі компетенції й досвід автора дозволяють здійснити відповідний аналіз зазначеної проблеми.

Перед безпосереднім оглядом системи вищого військового управління в УНР за часів ЦР варто звернути увагу на те, що їі становленню заважало багато причин. Серед внутрішніх чинників треба виділити брак часу, бо повноцінне військове будівництво провід ЦР і відповідне Генеральне Секретарство на чолі з С.Петлюрою змогли розпочати лише наприкінці листопада 1917 р. (після проголошення УНР у III Універсалі), а вже до початку лютого 1918 р. було втрачено більшість державної території включно зі столицею - Киевом [5, с. 382-394]. Додаткові труднощі обумовила відсутність чіткого плану військового будівництва, бо провід Республіки вагався між запровадженням народної міліції й потребою як збереження залишків українізованих i добровольчих формувань, так і творення повноцінних Збройних Сил. Певну роль відіграв й брак необхідної кількості військових фахівців 3 досвідом служби на керівних посадах у структурах російського вищого військового управління.

Попри зазначене головну роль у невдачах військового будівництва УНР взимку 1917-1918 рр. відіграв успішний наступ військ Радянської Росії, підтриманий загонами місцевої Червоної Гвардії, що призвів до розгрому військ ЦР і втрати контролю за більшістю територї України. Підкреслю й те, що все це відбувалось в умовах Першої світової війни, яку формально вела УНР на боці Антанти 
до початку лютого 1918 р. (9 лютого підписано сепаратний мирний договір між УНР та провідними державами «Четверного союзу» - Німеччиною й Австро-Угорщиною) [5, c. 412].

За таких обставин перші спроби утворити вище військове керівництво в УНР виявились невдалими. Більш успішними стали заходи проводу ЦР і військових фахівців вже після відновлення формального контролю над Киевом і більшістю території України (завдяки збройній підтримці нових союзників). Так, на початку березня 1918 р. Військовий міністр О. Жуковський призначив генерал-майора О. Осецького начальником Головного Штабу, а підполковника О. Сливинського Генерального Штабу [16, с.97]. Під їх керівництвом розпочалося відновлення структур вищого військового управління.

Згодом було розроблено й оголошено впровадження комплексної системи вищого військового керівництва у Збройних Силах УНР. Свідченням цих зрушень став наказ № 43 від 11 квітня 1918 р. [25, с. 42]. У цьому документі було наголошено на пріоритетності посади Військового міністра у тогочасній системі вищого військового управління в УНР, бо саме це міністерство мало забезпечувати утворення, утримання й підготовку Збройних Сил до оборони країни. 3 огляду на це інші структури вищого військового управління (Генеральний Штаб, Головний Штаб та Головний начальник постачання) підлягали у своій діяльності Військовому міністру.

Підкреслю, що у згаданому наказі було чітко й лаконічно окреслено повноваження й структуру кожної 3 основних гілок вищого військового управління [25, с. 43-45]. Так Генеральний Штаб, до складу якого входило 7 управлінь (у тому числі й Управління I Отаманквартирмайстра з 5 відділами та II Отаман-квартирмайстра 34 відділами), забезпечував здійснення мобілізації до війська, збір інформації про вірогідних противників i відповідні театри ймовірних бойових дій та інспектування військ. Головний Штаб (у його складі мало функціонувати 2 управління й одна управа та 2 відділи) мав забезпечити 
аналіз питань щодо особового складу Збройних Сил, запровадження й реалізацію пенсій для військовослужбовців та функціонування системи військової освіти. Останню гілку вищого військового керівництва уособлювало Управління Головного начальника постачання, яке було покликане забезпечити належне постачання усіх родів військ і структур Збройних Сил УНР, а тому складалося 34 управлінь і 4 управ та окремого технічного комітету.

Представлений комплекс вищого військового управління в УНР, на думку тогочасних українських військових фохівців, мав забезпечити адекватну реалізацію зазначених у наказі завдань і повноважень.

Після короткого огляду основних структур вищого військового управління Збройних Сил УНР варто наголосити на тому, що вони значною мірою наслідували дореволюційну російську систему центрального військового управління, зосереджену у Військовому міністерстві [26, с. 89-93]. Згадана система на початку XX ст. набула певної дієздатності й забезпечила функціонування найбільших у Свропі Збройних Сил. При цьому вона мала не тільки сильні сторони, але й певні недоліки (заплутаність повноважень i структурного поділу Генерального Штабу / Головного Управління Генерального Штабу; суперечності між окремими структурними одиницями тощо), більшість 3 яких було виявлено вже за часів Першої світової війни [27; 28].

Наголошу, що українська структура вищого військового управління у квітні 1918 р. виявляє особливості як суто військового будівництва, так i тогочасного розвитку державної системи. Так, у військовому контексті помічається не лише чіткість i функціональність представленої системи, але й певна невідповідність окремих структурних підрозділів. Прикладом цього $є$ не тільки включення Головних військово-юридичної та військово-геодезичної управ до відомства Головного начальника постачання, але й роздільне підпорядкування мобілізаційного відділу 
Управлінню II Отаман-квартирмайстра Генерального Штабу, а демобілізаційного відділу - Головному Штабу.

Поряд із суто військово-організаційним аналізом діездатності вищого військового управління зразка 11 квітня 1918 р. варто відзначити й намагання під час його розробки врахувати пріоритети тогочасного розвитку УНР. Маю на увазі той факт, що в Україні тоді функціонувала парламентська республіка на чолі з ЦР. 3 огляду на це й Збройні Сили УНР підпорядковувались через Військове міністерство Центральній Раді, яка відповідним чином призначала Військового міністра i доручала йому реалізовувати певну програму військового будівництва 3 урахуванням політичних пріоритетів домінуючих партійних фракцій. Поряд із цим помічається націленість і на розбудову військової системи за мирних умов, гарантом чого була присутність німецьких та австро-угорських військ.

Поряд із згаданими військовими відомствами за часів ЦР робилися спроби створити й розвинути інші вищі структури регіонального управління, але їх огляд виходить за межі передбаченого дослідження. Треба мати на увазі, що діяльність УНР була перервана 29 квітня 1918 р. завдяки державному перевороту, внаслідок якого почалося створення та короткочасне функціонування Української Держави Гетьмана П.П. Скоропадського [5, c. 421]. За таких обставин, вочевидь, не вдалося повною мірою реалізувати проект розбудови структур вищого військового управління від 11 квітня 1918 р.

Відновлення УНР відбулося внаслідок повстання проти П.П. Скоропадського, яке розпочалося 15 листопада 1918 р. під проводом Директорії [5, с. 452]. Враховуючи особливості військово-повстанської стихії й відсутність единих підходів щодо військового будівництва в УНР, досить функціональний проект вищого військового управління з'явився лише в лютому 1919 р. Свідченням цього став наказ № 60 Військового міністра О. Грекова $[29$, с. 15]. Згідно з цим наказом на чолі Українського війська (як кадрового, так і дієвого) мав стояти Головний Отаман Республіканських військ Симон Петлюра. 
Далі подається короткий огляд структури вищого військового управління (за виключенням Дієвої армї, що мала окрему структуру управління). На його чолі перебував Військовий міністр, якому згідно з наказом мали підпорядковуватися на правах заступників (товаришів міністра) начальник Генерального Штабу, Головний начальник постачання та Головний інспектор Військ УНР, а на правах начальників Головних управлінь начальник канцелярії міністра, начальник Головного військово-юридичного управління, Інспектор Військ УНР по справах національно-культурно-освітніх та Голова управи військового духівництва [29, с. 15-20]. Поряд із цим було окреслено структуру та повноваження Генерального Штабу (відбулося виділення Головного Управління Генерального Штабу - ГУГШ; Генеральному Штабу було підпорядковано Головний Штаб), Головного начальника постачання (мало фрункціонувати 4 управління і 3 управи) та Головного інспектора Військ УНР (мусив забезпечувати інспектування піхоти, кавалерії, артилерії та технічних частин).

Наведена інформація засвідчила той фракт, що під час творення згаданої системи вищого військового управління мало місце використання як попередніх українських, так i частково дореволюційних російських взірців (у структурному вимірі та визначенні повноважень). Загалом, в лютому 1919 р. розпочалося впровадження досить комплексної й структурованої системи вищого військового управління в УНР. У представленій системі видається логічним підпорядкування безпосередньо Військовому міністру Головного військово-юридичного управління та створення й підпорядкування структур Інспектора 3 національно-культурно-освітніх справ та управи військового духівництва. До речі, структуру Інспектора 3 національно-культурно-освітніх справ було створено в українських реаліях без орієнтації на російські дореволюційні аналоги. В умовах гострої збройної боротьби, що супроводжувалась активною політичною агітацією й пропагандою, такий крок видається слушним i виправданим. Окремо наголошу на слушному укрупненні 
Генерального Штабу за рахунок підпорядкування Головного Штабу та окремих Головної шкільної і Головної геодезичної управ. Відзначу й виділення ГУГШ, що значною мірою збігаеться з пріоритетами фрунціонування відповідної структури у вищому військовому управлінні ще дореволюційної армії Російської імперії [26, с. 89-92; 27]. Поряд із позитивними зрушеннями відзначу й певні недоліки. Так, видається слушним Головне управління повітряного фрлоту передати 3 відомства Головного начальника постачання до Генерального Штабу. До того ж новостворене Морське відомство, попри відсутність значного військового потенщіалу, залишилося самостійним й діяло поза Військовим міністерством.

Ведучи мову про зазначені зміни, варто підкреслити їх залежність від тогочасних реалій військово-політичної ситуації в УНР. Маю на увазі зміну геополітичної ситуації в Свропі й світі через перемогу Антанти, що обумовило капітуляцію й вихід 3 України німецьких та австроугорських військ та перемогу повстання проти Гетьмана П.П. Скоропадського під проводом Директорії. Наголошу й на укладанні Акта Злуки між УНР і ЗУНР, що обумовило відкриття Наддніпрянською армією УНР фронту проти Війська Польського в умовах потужного наступу Червоної Армії. Все це відбувалось на тлі гострої соціально-економічної й політичної кризи та розгортання широкомасштабного повстанського руху.

За цих обставин в УНР відбувся відхід від попередньої моделі парламентської республіки на чолі 3 ЦР. Керівництво зосередилося в руках Директорії, яка частково легітимізувалася через проведення в Києві 23-28 січня 1919 р. Трудового конгресу [30, с. 167]. Більше того, через кардинальне зростання ваги Наддніпрянської армії в умовах військово-політичної кризи січня-лютого 1919 р. провідна роль в Директорії поступово переходила до С. Петлюри, який перебував на посаді Головного Отамана Республіканських військ. Такі реалії й було зафіксовано у наказі Військового міністра - пріоритетність у системі вищого військового управління в УНР (як у кадровій, так і дієвій арміях) саме Головного 
Отамана С. Петлюри. Інакше кажучи, помічається тенденція зростання впливу цього діяча, який у складній військово-політичній та соціально-економічній ситуації очолював військову систему УНР, здобуваючи позицію провідника Директорії, a, отже, і держави.

До речі, розбудова військової системи взимку 1919 р. відбувалася й орієнтувалася саме на потреби важкої збройної боротьби на різних фрронтах як 3 іноземною інтервенцією, так і внутрішніми противниками.

Підсуловуючи огляд систем вищого військового управління УНР за часів ЦР (квітень 1918 р.) та Директорії (лютий 1919 р.), треба відзначити наступне:

1. Спроби запровадження нових систем вищого військового управління свідчили про логічне намагання покращити українське військове будівництво.

2. Вони відбувалися вже після перших кроків у цьому напрямі, які виявились невдалими через відсутність досвіду чи певну хаотичність і спонтанність дій на тлі військових поразок.

3. Важливим виявився вплив дореволюційних російських взірців вищого військового управління 3 огляду на їx фоннкціональність i відповідний досвід українських військових фрахівців.

4. Пріоритети військового управління чітко співвідносилися із засадами тогочасного державного розвитку УНР і враховували військово-політичну та соціально-економічну ситуацію як в Україні, так і поза їі межами.

5. Пропоновані структури управління, визначені межі ï повноважень та співвідношення між їх складовими мали ознаки достатньої функціональності.

6. Обидві системи мали певні недоліки, проте в лютому 1919 р. їх виявлено менше, до того ж мало місце виправлення помилок, які були присутні в попередні часи.

Таким чином, за часів ЦР у квітні 1918 р. та Директорії у лютому 1919 р. здійснювалися змістовні спроби вдосконалення системи вищого військового 
управління Збройних Сил УНР, на яких позначився й вплив дореволюційних російських аналогів. Попри наявність певних недоліків пропоновані системи не лише відповідали нагальним потребам військового будівництва, але й враховували тенденції тогочасного державнополітичного розвитку України у контексті відповідної геополітичної ситуації. При цьому більш змістовною виявилася спроба, розпочата за часів Директорії в лютому 1919 р., в якій ще й було виправлено окремі недоліки попередніх розробок.

Представлена стаття не вичерпуе проблематики становлення системи вищого управління Українського Війська часів революції 1917-1921 рр., а лише розкриває

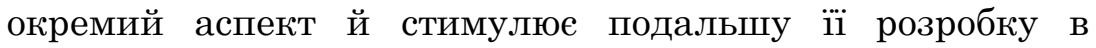
історіографії.

1. Зілінський B. Синьожупанники / В. Зілінський. Берлін, 1938. - 75 с.

2. Капустянський $M$. Похід українських армій на Київ Одесу в 1919 році / М. Капустянський. - К.: Темпора, 2004. - С. 19-286.

3. Петрів В. Військово-історичні прац і. Спомини /

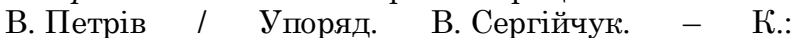
Поліграфкннига, 2002. - С. 56-236.

4. Удовиченко О. Україна у війні за державність 1917-1921 / О. Удовиченко. - Вінніпег, 1954. - 476 с.

5. Історія Українського Війська (від княжих часів до 20-х років ХХ ст.) / Зав. ред. Д.С. Карпин. - Львів: Світ, 1992. - $702 \mathrm{c.}$

6. Гарчев П. Червона гвардія України у боротьбі за Владу Рад / П. Гарчев. - К.: Вища школа, 1983. $152 \mathrm{c.}$

7. Лихолат А.В. Розгром нащіоналістичної контрреволюції на Україні / А.В. Лихолат. - К.: Держполітвидав УРСР, 1955. - 662 с.

8. Супруненко Н. Очерк истории Гражданской войны и иностранной военной интервенции на Украине 1918-1920 / Н. Супруненко. - К.: Наука, 1966. $420 \mathrm{c.}$

9. Гарчева Л. Збройні Сили Центральної Ради у лютому-квітні 1918 року / Л.Гарчева // Військо України. - 1993. - № 8. - С. 102-107.

10. Якимович Б. Збройні сили України: нарис історії / Б. Якимович. - Львів: Інститут українознавства iм. І. Крип'якевича НАНУ, «Просвіта», 1996. - 360 с. 
11. Пархоленко В. Військові формування Центральної Ради в Одесі у 1917-1918 рр. / В. Пархоменко // Наукові праці. - Т. 2. Історичні науки. - Миколаїв: МФНаУКМА, 1999. - С. 39-42.

12. Ткачук П.П. Сухопутні війська України доби революції 1917-1921 рр.: монографрія / П.П. Ткачук. Інститут українознавства ім. І. Крип'якевича НАНУ, Львівський інститут Сухопутних військ НУ «ЛП». - Львів, 2009. - 312 с.

13. Ткачук П.П. Артилерія збройних формувань української революції 1917-1921рр. / П.П. Ткачук // Матеріали науково-практичної конференщії «Соціально-економічні, психологічні та історичні аспекти трансформації Збройних Сил України».Київ, 2009. - С. 354-357.

14. Колянчук $O$. Генералітет українських визвольних змагань. Біограми генералів та адміралів українських військових формацій першої половини XX століття / О. Колянчук, М. Литвин, К. Науменко. Львів: Ін-т українознавства ім. І. Крип'якевича НАН України, 1995. - 283 с.

15. Тинченко Я. Офіцерський корпус Армії Української Народної Республіки (1917-1921) / Я. Тинченко. К.: Темпора, 2007. - 536 с.

16. Тинченко Я. Офіцерський корпус Армії Української Народної Республіки (1917-1921). Книга II / Я. Тинченко. - К.: Темпора, 2011. - 429 с.

17. Задунайський В. Ранги та посади Наддніпрянської Армії / В. Задунайський // Київська старовина. 1994. - № 4. - C. 104-110.

18. Задунайський B. Українські козацько-лицарські традиції в Наддніпрянській армії УНР (1917-1919 рр.) / В. Задунайський // Схід. - 2001. № 3. - C. 60-62.

19. Задунайський $B$. Бойове мистецтво та військова спадщина українських козаків в кінщі XIX - на початку XXI ст. / В. Задунайський. - Донецьк: Норд-Прес - ДонНУ, 2006. - 335 с.

20. Задунайський $B$. Військово-судова система Українського Війська за часів Української Центральної Ради / В. Задунайський // Вісник Донецького національного університету. Серія Б. Гуманітарні науки / Гол. ред. В.П. Шевченко. Донецьк, 2009. - № 1. - С. 110-116.

21. Задунайський B. Становлення засад військової дисципліни в Українському Війську (кінець 1917 - 
квітень 1918 рр.) / В. Задунайський // Наукові праці історичного фракультету Запорізького національного університету. - Запоріжжя: ЗНУ, 2009. Вип. XXVII. - С. 109-113.

22. Задунайський $B$. Військова співпраця Збройних Сил УНР та російських козацьких формувань восени 1920 р. Військова співпраця Збройних Сил УНР та російських козацьких формувань восени 1920 р. / В. Задунайський // Схід. - 2010. - № 5. - С. 91-93.

23. Karpus $Z$. Wschodnisojusznicy Polskiwwojnie 1920 roku / Z. Karpus. - Toruc: Wydawnictwo UMK, 1994. - $230 \mathrm{~s}$.

24. Skrukwa G. Formacje wojskowe Ukraicskiej «rewolucji narodowej» 1914-1921 / G. Skrukwa. Toruc: Wydawnictwo Adam Marszaiek, 2008. - 717 s.

25. ЦДАВО України. Ф. 1076, оп. I, спр. 15.

26. Василевский Н.А. Руководство для штаб-офицеров и капитанов, подвергающихся испытанию при зачислении в кандидаты на должности уездных воинских начальников, и Справочная книга для уездных воинских начальников / Н.А. Василевский. Спб.: Комессионер Военно-учебных заведений В. Березовский, 1910. - 793 с.

27. Верелеев Ю. Генеральный штаб Русской армии. Штаб, которого не было [Електронний ресурс]/ Ю. Веремеев. - Режим доступу: http://army.armor.kiev.ua/ hist/genstab-1894.php.

28. Драгомиров B. Подготовка русской армии к Великой войне [Електронний ресурс] / В. Драгомиров // Военный сборник общества ревнителей военных знаний. Книга 4. - Белград, 1923. - Режим доступу: http://grwar.ru/library/ Dragomiroff-Prepare/DV_01.html.

29. ЦДАВО України. Ф. 1075, оп. 1, спр. 15.

30. Задунайський В.Трудовий Конгрес України / В. Задунайський // Енщиклопедія історії України в 10 т. / Гол. ред. ради В.М. Литвин. - Т. 10. - К.: Наукова думка, 2013. - С. 167-168.

Надійшла до редколегії 07.02.2017 p.

Рецензент: П.П. Ткачук, доктор історичних наук, професор, заслужений діяч освіти України, начальник Національної академії сухопутних військ імені гетьмана Петра Сагайдачного, м. Львів. 
Задунайский В.В.

СТРУКТУРА ВЫСШЕГО УПРАВЛЕНИЯ ВОЙСК УКРАИНСКОЙ НАРОДНОЙ РЕСПУБЛИКИ ВО ВРЕМЕНА ЦЕНТРАЛЬНОЙ РАДЫ (апрель 1918 г.) И ДИРЕКТОРИИ (февраль 1919 г.): ОБЩЕЕ И РАЗЛИЧНОЕ

Структура высшего управления войск УНР во времена Центральной Рады (в апреле 1918 г.) и Директории (в феврале 1919 г.) была достаточно фрункџиональной. Система 1919 года была более удачной - исправлено предыдущие ошибки (создано Главное управление Генерального штаба; Генеральный штаб контролировал Главный штаб и Главную школьную и Главную геодезическую управы). Структура высшего военного управления соответствовала требованиям военно-политической ситуации. В апреле 1918 г. УНР находилась под защитой войск Германии и Австро-Венгрии. В УНР действовала парламентская модель - доминировала ЦР (во главе Вооруженных Сил стоял Военный министр). В фоеврале 1919 года в УНР не было международной поддержки и она потеряла часть территории (Красная Армия и Войско Польское разгромили украинские войска). Во главе УНР стояла Директория, в которой доминировал Главный Атаман Петлюра (он возглавил Вооруженные Силы).

Ключевые слова: Высшее военное управление, Украинская Народная Республика, Центральная Рада, Директория, Вооруженные Силы, Военный министр, Генеральный штаб, Главный штаб.

\section{Zadunaiski V.}

HEAD MANAGEMENT STRUCTURE FORCE OF UKRAINIAN PEOPLE'S REPUBLIC OF CENTRAL COUNCIL TIMES (APRIL 1918) AND DIRECTORY (FEBRUARY 1919): COMMON AND DISTINCTIVE

Head management structure UPR troops in the days of of the Central Rada (April 1918) and the Directory (in February 1919) was quite functional. System of 1919 was more successful - corrected previous mistakes (created Department of General Staff, General Staff controlled main headquarters and main School council and Geodetic school).The structure of the higher military administration complies with the requirements the military and political situation. In April 1918, the UPR was under the protection of the forces of Germany and Austria-Hungary. The UPR acted parliamentary model - dominated CR (at the head of the Armed Forces was Minister of War).In February 1919, UPR did not have international support, and it lost a part of the territory (the Red Army and the Polish Army defeated the Ukrainian troops). At the head of the UPR was the Directory in which dominated Chief Ataman Petliura (he headed the Armed Forces).

Keywords: Higher military government, the Ukrainian People's Republic, Central Rada, Directory, Armed Forces, Minister of War, General Staff, the Main Staff. 